\title{
Quantitative RT-PCR assay for VEGF mRNA in human tumors of the kidney
}

\author{
C. TRICARICO ${ }^{1}$, B. SALVADORI ${ }^{1}$, D. VILLARI ${ }^{2}$, G. NICITA $^{2}$, A. DELLA MELINA ${ }^{2}$, P. PINZANI $^{1}$, \\ M. $\mathrm{ZICHE}^{3}$, M. PAZZAGLI ${ }^{1}$ \\ ${ }^{1}$ Department of Clinical Physiopathology \\ ${ }^{2}$ Department of Urology \\ ${ }^{3}$ Department of Pharmacology, University of Firenze, Firenze - Italy
}

\begin{abstract}
Angiogenesis is the formation of new capillaries from pre-existing vessels, and recent evidence has demonstrated that tumor growth is controlled mainly by angiogenesis. Vascular endothelial growth factor (VEGF) is an endothelium-specific growth factor which is strongly angiogenic in vitro and in vivo. We have developed a quantitative RT-PCR assay for the measurement of VEGF $m R N A$ expression using a real-time procedure based on the use of fluorogenic probes and the ABI PRISM 7700 Sequence Detector System. The assay performance of this method in terms of practicability and reliability is reported with results that seem promising for its widespread use in the clinical laboratory. The method has been applied to the measurement of $m R N A$ of VEGF in human renal cell carcinomas (RCC). Preliminary results show a significantly higher VEGF mRNA expression (ratio values between 181 and 2222) in tumor specimens compared to non-adjacent, non-tumoral tissue of the same subjects. (Int J Biol Markers, 1999; 14: 247-50)
\end{abstract}

KEY WORDS: TaqMan, Quantitative RT-PCR, VEGF, Renal tumors

\section{INTRODUCTION}

Several factors have been shown to display angiogenic activity. Among these factors vascular endothelial growth factor (VEGF) appears to play a key role in tumor angiogenesis (1). Increased VEGF mRNA levels have been observed in various kinds of tumors including kidney tumors (2-4). In particular upregulation of VEGF expression has been reported in tumors compared with non-tumoral, non-adjacent tissue of the same subjects.

We have developed a quantitative RT-PCR assay for the measurement of VEGF mRNA expression using a real-time procedure based on the use of fluorogenic probes and the ABI PRISM 7700 Sequence Detector System (5). With this method we have investigated the levels of VEGF mRNA expression in six renal tumor specimens and in the corresponding non-adjacent, nonneoplastic tissue from the same kidneys.

\section{MATERIALS AND METHODS}

Patients and specimens

Six RCC tumors have been characterized by histotype, tumor size, stage (TNM) and grade (Fuhrman) (6). Clinical data are summarized in Table I. RNA was extracted from renal tissues by conventional phenolchloroform extraction.

\section{Real-time RT-PCR assay}

The TaqMan ${ }^{\mathrm{TM}}$ principle has recently been described in detail. Briefly, the method is based on the use of fluorogenic probes labeled both with a fluorescence emitter and a fluorescence quencher. The special fluorogenic TaqMan probe has been designed to hybridize within the target sequence and to generate a signal that accumulates during PCR cycling in a manner proportional to the con- 
centration of amplification products. The fluorescence emission is monitored in real time (5). The $\Delta \mathrm{Rn}$ values reflect the quantity of degraded fluorescent probe and fit an exponential function generating an amplification plot for each sample (Fig. 1). At the same time the algorithm determines an experimental threshold. The number of the cycle at which the fluorescence of each sample reaches this threshold $(\mathrm{Ct})$ is proportional to the number of target copies present in the initial sample. The $\mathrm{Ct}$ of each sample is utilized to quantitate the specific mRNA, using a standard curve generated with an RNA standard (Fig. 2). Finally, the VEGF mRNA concentration in samples is expressed as molecules/ $\mu \mathrm{g}$ total RNA.

\section{RESULTS}

\section{VEGF mRNA assay performance}

As mentioned in the introduction, by using realtime quantitative RT-PCR the specific RNA in the sample is reversely transcribed, amplified and quantitated without any further downstream processing, thus decreasing the risk of contamination. In fact, the use of fluorogenic probes allows the development of a homogeneous assay with excellent characteristics in terms of analytical quality and practicability. In our experiments the standard curve points, control sam-
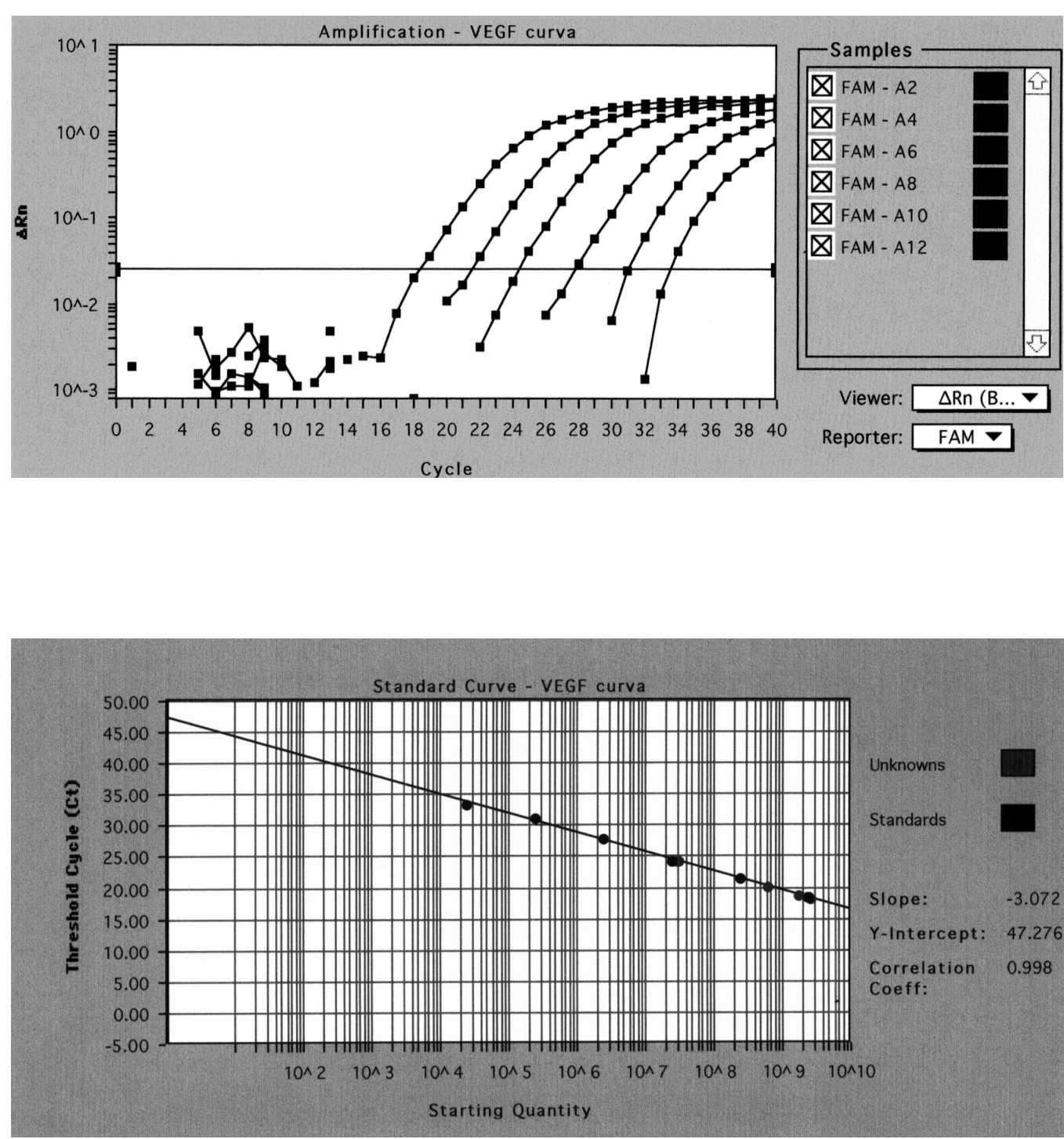

Fig. 1 - Amplification plots in TaqMan technology: $\Delta R n$ (emission intensity of the reporter dye) vs cycle number for VEGF gene expression performed at six points with increasing amounts of standard.

Fig. 2 - Standard curve for VEGF gene expression reported as starting quantity (in molecule number vs threshold cycle $(\mathrm{Ct})$. Points refer to the experiment and amplification plot described in Figure 1. 
ples and unknown samples were elaborated in triplicate after retrotranscription.

As an example of the performance of the VEGF mRNA RT-PCR assay we report the reproducibility data of the calibration curve (see Fig. 3). The practicability of the proposed method (assay in microtiter plate format and in homogeneous phase can perform amplification steps and analysis of the results in 4-6 hours) is also satisfactory and both these aspects indicate that this type of technique should be widely adapted in the clinical laboratory in the near future.

\section{VEGF mRNA expression levels in tumors of the kidney}

The proposed method has been applied to VEGF mRNA measurement in six renal tumors. A significant increase in VEGF has been observed in tumors (mean value $9.2 \times 10^{7}$ VEGF mRNA molecules/ $\mu$ g total RNA) compared to non-adjacent non-neoplastic tissue (mean value $1.6 \times 10^{5}$ VEGF mRNA molecules/ $\mu$ g total RNA, $\mathrm{p}<0.05)$ (Tab. II) with a ratio ranging from 181 to 2222.

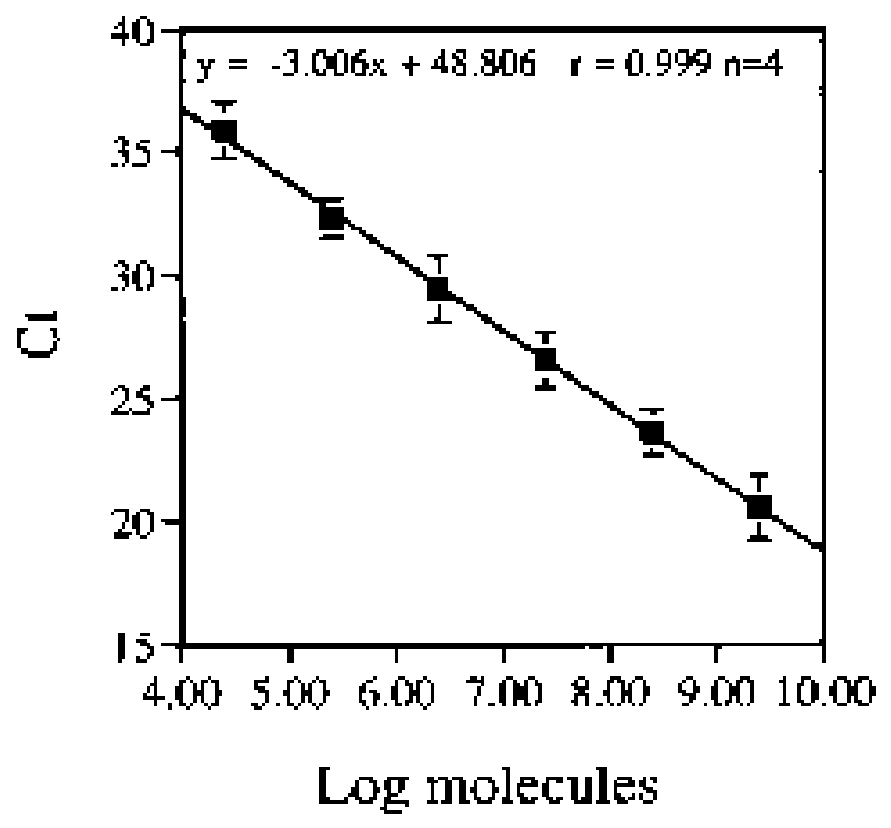

Fig. 3 - Calibration curve reproducibility obtained as mean $\pm S D$ of four different assays.

TABLE I - CLINICAL DATA AND HISTOLOGICAL TYPE OF SIX PATIENTS AFFECTED BY RENAL CARCINOMA

\begin{tabular}{|c|c|c|c|c|c|}
\hline Sample & $\begin{array}{l}\text { Age } \\
\text { yrs/sex }\end{array}$ & $\begin{array}{l}\text { Stage } \\
\text { (TNM) }\end{array}$ & $\begin{array}{l}\text { Grading } \\
\text { (Fuhrman) }\end{array}$ & $\begin{array}{l}\text { Histological } \\
\text { type }\end{array}$ & $\begin{array}{c}\text { Tumor } \\
\text { diameter }(\mathrm{cm})\end{array}$ \\
\hline B.B. & $73 / \mathrm{F}$ & pT2 & $\mathrm{G} 2$ & Clear cell & $3.3 \times 3.8 \times 3$ \\
\hline P.L. & $60 / \mathrm{M}$ & pT2 & $\mathrm{G} 2$ & Clear cell & $15 \times 14.5 \times 11$ \\
\hline C.B. & 49/M & pT1 & $\mathrm{G} 2$ & Clear cell & $3.6 \times 3.2 \times 3$ \\
\hline S.R. & $51 / \mathrm{M}$ & pT2 & G3 & Clear cell & $9 \times 8 \times 8$ \\
\hline T.A. & $66 / F$ & pT3a & G4 & Sarcomatoid & - \\
\hline T.G. & $84 / \mathrm{M}$ & pT1 & G2 & Papillary & $2.5 \times 2 \times 1.8$ \\
\hline
\end{tabular}

TABLE II - VEGF LEVELS AND RATIO IN TISSUE SPECIMENS OF KIDNEY TUMORS AND IN THE CORRESPONDING NON-NEOPLASTIC TISSUE

\begin{tabular}{|c|c|c|c|}
\hline Patient & $\begin{array}{l}\text { VEGF in normal kidney tissue } \\
\text { molecules/ } \mu \mathrm{gRNA} \text { tot }\end{array}$ & $\begin{array}{l}\text { VEGF in kidney tumor } \\
\text { molecules/ } \mu \mathrm{gRNA} \text { tot }\end{array}$ & $\begin{array}{l}\text { VEGF ratio in kidney } \\
\text { tumor/normal tissue }\end{array}$ \\
\hline B.B. & $4.3 \times 10^{5}$ & $3.7 \times 10^{8}$ & 860.47 \\
\hline P.L. & $1 \times 10^{5}$ & $3.1 \times 10^{7}$ & 310 \\
\hline C.B. & $4.3 \times 10^{4}$ & $7.8 \times 10^{6}$ & 181.40 \\
\hline S.R. & $7.1 \times 10^{4}$ & $3.8 \times 10^{7}$ & 535.21 \\
\hline T.A. & $3.5 \times 10^{5}$ & $9.8 \times 10^{7}$ & 280 \\
\hline T.G. & $2.7 \times 10^{3}$ & $6 \times 10^{6}$ & 2222 \\
\hline
\end{tabular}




\section{DISCUSSION}

We have developed an assay suitable for the measurement of VEGF mRNA expression. Other authors have already reported quantitative RT-PCR assays for VEGF but with different analytical approaches. Fujimoto et al (7) employed primers suitable for monitoring the expression of all the VEGF isoforms and expressed the results as relative units with respect to the GAPDH reference gene. These authors observed a markedly higher VEGF expression in uterine cervical cancer but they did not find any significant difference in the expression pattern of VEGF121 and VEGF165 in comparison to normal cervical tissue. Ikeda et al (8) and Wong et al (9) quantified the expression pattern of the VEGF isoforms and expressed the results as relative units to the $\beta$-actin reference gene. Ikeda et al (8) reported a relative increase in VEGF mRNA expression in $67.5 \%$ of pancreatic cancers. Wong et al (9) observed a mean increase of total VEGF mRNA expression both in colorectal adenomas and carcinomas in comparison to normal colon tissue. Finally Thelen et al (10) and Boldrini et al (11) developed a quantitative RT-PCR assay for VEGF isoforms based on the use of competitors. In this case the assay results are expressed as attomoles of VEGF/ $\mu \mathrm{g}$ of total cellular RNA. Thenel et al (10) reported an increase in VEGF expression in renal cell carcinoma in comparison to normal tissue. Boldrini et al (11) obtained similar results in non-small cell lung carcinomas. In spite of a consistently observed mean increase in VEGF expression in various tumors, the dif- ferent analytical approaches used by the various authors do not allow direct comparison of the results.

In conclusion, the method proposed here includes several novel aspects with respect to previously reported methods, in particular the use of fluorogenic probes and the adequate performance and practicability. This approach seems therefore appropriate for extensive study of the role of VEGF expression in tumors, and the preliminary results observed in a limited number of tumors of the kidney are suggestive of an important role of the measurement of this growth factor in tumor specimens. However, correlation studies between these data and other clinical or diagnostic parameters are required in larger patient series before quantification of VEGF expression can be considered as a suitable index of tumor growth and metastasis.

\section{ACKNOWLEDGEMENTS}

This work was supported by a grant of the Azienda Ospedaliera Careggi (Progetti Qualità No. 60a and 94a) and by the University of Florence (60\%).

Address for correspondence:

Prof. Mario Pazzagli

Unità di Biochimica Clinica

Università di Firenze

Viale Pieraccini, 6

50139 Firenze, Italy

\section{REFERENCES}

1. Folkman J. Angiogenesis in cancer, vascular, rheumatoid and other disease. Nature Med 1995; 1: 27-31.

2. Neufeld G, Cohen T, Gengrinovitch S, Poltorak Z. Vascular endothelial growth factor (VEGF) and its receptors. FASEB J 1999; 13: 9-20.

3. Takahashi A, Sasaki H, Kim S, et al. Markedly increased amounts of messenger RNAs for vascular endothelial growth factor and placenta growth factor in renal cell carcinoma associated with angiogenesis Cancer Res 1994; 54: 4233-7.

4. Brown LE, Berse B, Jackson RW, et al. Increased expression of vascular permeability factor (vascular endothelial growth factor) and its receptors in kidney and bladder carcinomas. Am J Pathol 1995; 143: 1255-62.

5. Orlando C, Pinzani P, Pazzagli M. Developments in quantitative PCR. Clin Chem Lab Med 1998; 36: 255-70.

6. Spiessl B, Beahrs OH, Hermanek P, et al. In: TNM-Atlas. Berlin: Springer Verlag 1992; 3: 261-9.
7. Fujimoto J, Sakaguki H, Hirose R, Ichigo S, Tamaya T. Expression of vascular endothelial growth factor (VEGF) and its mRNA in uterine cervical cancers. Br J Cancer 1999; 80: 827-33.

8. Ikeda N, Adachi M, Taki T, et al. Prognostic significance of angiogenesis in human pancreatic cancer. Br J Cancer 1999; 79: 1553-63.

9. Wong MP, Cheung N, Yuen ST, Leung SY, Chung LP. Vascular endothelial growth is up-regulated in the early pre-malignant stage of colorectal tumor progression. Int J Cancer 1999; 80: 845-50.

10. Thelen P, Hemmerlein B, Kugler A, et al. Quantification by competitive quantitative RT-PCR of VEGF121 and VEGF165 in renal cell carcinoma. Anticancer Res 1999; 19: 1563-5.

11. Boldrini L, Calcinai A, Silvestri V, et al. Quantitation by competitive PCR assay of vascular endothelial growth factor in non small cell lung carcinomas. Int J Oncol 1999; 14: 161-8. 